(2) Open Access Full Text Article

\title{
Upper limit of the normal range for thyrotropin- stimulating hormone is higher with increasing age
}

Oscar MP Jolobe

Manchester Medical Society, Manchester, United Kingdom

Correspondence: Oscar MP Jolobe I Philip Godlee Lodge, 842 Wilmslow Road, Manchester M20 2DS, UK Tel +44 I6 I4489034

Email oscarjolobe@yahoo.co.uk
This article was published in the following Dove Press journal:

Clinical Interventions in Aging

31 July 2012

Number of times this article has been viewed

\section{To the editor}

The assertion that aging is associated with a decreasing concentration of thyrotropin-stimulating hormone (TSH) in healthy elderly humans ${ }^{1}$ appears to be at odds with the observation that "TSH distribution shifts towards higher concentrations with age."' The latter conclusion was based on a study that analyzed the age-specific distribution of serum TSH in 14,376 disease-free subjects with negative thyroid antibody tests. In that study, the percentage of TSH measurements in the $2.5-4.5 \mathrm{mIU} / \mathrm{L}$ range progressively increased with age from approximately $6.5 \%$ in the $20-29$-year age group to $23.9 \%$ in the 80 years and older age group. Likewise, the percentage of TSH measurements in the $>4.5 \mathrm{mIU} / \mathrm{L}$ category progressively increased from $2.0 \%$ in the $20-29$-year age group to $12 \%$ in the 80 years and older age group.

According to the authors of the study, a corollary of these findings is that "the currently accepted high prevalence of subclinical hypothyroidism in older people, based on the current upper limit of the reference range, $4.5 \mathrm{mIU} / \mathrm{L}$, may be an overestimate." ${ }^{2}$ Extreme longevity also appears to be associated with an increase in TSH levels, at least in Ashkenazi Jews. ${ }^{3}$ In the latter study, TSH levels were compared in 232 Ashkenazi subjects of median age 97.7 years versus their younger, unrelated counterparts, consisting of 95 females of median age 69.7 years and 95 males of median age 72.3 years. All subjects were free of thyroid disease and also free of acute or debilitating medical conditions. The principal finding was that serum TSH was significantly $(P<0.001)$ higher in the older age group (consisting of 232 subjects) than in their younger counterparts (consisting of 190 subjects) in spite of the fact that the serum thyroxine levels were similar. Further analysis revealed that the percentage of subjects with TSH $>2.5 \mathrm{mIU} / \mathrm{L}$ was $35.2 \%$ in the older subjects versus $15.4 \%$ in the younger subjects. ${ }^{3}$

\section{Disclosure}

The author reports no conflicts of interest in this work.

\section{References}

1. Bensenor IM, Olmos RD, Lotufo PA. Hypothyroidism in the elderly: diagnosis and management. Clin Interv Aging. 2012;7:97-111. 
2. Surks MI, Hollowell JG. Age-specific distribution of serum thyrotropin and antithyroid antibodies in the US population: implications for the prevalence of subclinical hypothyroidism. $J$ Clin Endocrinol Metab. 2007;92:4575-4582.
3. Atzman G, Barzilai N, Hollowell JG, Surks MI, Gabriely I. Extreme longevity is associated with increased serum thyrotropin. J Clin Endocrinol Metab. 2009;94:1251-1254. 


\section{Authors' response}

\author{
Isabela M Bensenor ${ }^{1,2}$ \\ Paulo A Lotufo',2
}

'Division of Internal Medicine, ${ }^{2}$ Department of Internal Medicine, School of Medicine, University Hospital, University of São Paulo, São Paulo, Brazil

Correspondence: Isabela M Bensenor

University Hospital, Av Lineu Prestes 2565, $3^{\circ}$ Andar, Centro de

Pesquisa Clínica, CEP 05508-000, Brazil

Tel +55 II 309| 9300

Fax +55 I| 309| 924I

Email isabensenor@hu.usp.br

We welcome these comments from Dr Jolobe. An increase in thyrotropin-stimulating hormone (TSH) with aging has been shown in several population-based studies, including the Whickham survey, ${ }^{1,2}$ the National Health and Nutrition Examination Survey, ${ }^{3}$ and in a Framingham Heart Study cohort. ${ }^{4}$ Our text was clear about the increase in TSH levels with aging observed in these large epidemiologic studies. ${ }^{5}$ However, other cross-sectional studies compared thyroid function in older subjects including centenarians with young controls. ${ }^{6-8}$ Some of these studies did not show higher TSH levels in centenarians compared with young older people and young controls. ${ }^{6,7}$ Mazzoccoli et al carried out a study in 15 healthy, young, middle-aged subjects (aged 36-55 years) and 15 healthy elderly subjects (aged 67-79 years). Serum levels of thyrotropin-releasing hormone, TSH, and free thyroxine (T4) were measured in samples collected every four hours for 24 hours. Elderly subjects had lower TSH levels, but there was no statistically significant difference in TRH and serum free thyroxine levels between young, middle-aged, and elderly subjects. ${ }^{8}$ In general, these studies have been done in a small number of individuals, and have restricted the analyses to healthy subjects. One possible explanation for a mild decrease in TSH levels in some older people could be increased sensitivity to physiologic negative feedback by thyroxine. ${ }^{8,9}$ As our text stated, the low serum concentrations of TSH result in a decline in serum total and free $\mathrm{T} 3$ levels, but the reduction in both $\mathrm{T} 4$ secretion and peripheral $\mathrm{T} 4$ degradation results in no change in serum total and free $\mathrm{T} 4$ concentrations. Although Dr Jolobe's letter suggests putative conflicting results, this is unlikely, ${ }^{10}$ because the data presented in the review refer to studies with different designs that have to be interpreted in the proper context.

\section{Disclosure}

The authors report no conflicts of interest in this work.

\section{References}

1. Tunbridge WM, Evered DC, Hall R, et al. The spectrum of thyroid disease in a community: the Whickham survey. Clin Endocrinol. 1977;7(6):481-493.

2. Vanderpump MP, Tunbridge WM, French JM, et al. The incidence of thyroid disorders in the community: a twenty-year follow-up of the Whickham Survey. Clin Endocrinol. 1995;43(1):55-68.

3. Hollowell J, Staehling NW, Flanders D, et al. Serum TSH, T4, and thyroid antibodies in the United States population (1988 to 1994): National Health and Nutrition Examination Survey (NHANES III) J Clin Endocrinol Metab. 2002;87(2):489-499.

4. Sawin CT, Castelli WP, Hershman JM, McNamara P, Bacharach P. The aging thyroid. Thyroid deficiency in the Framingham Study. Arch Intern Med. 1985;145(8):1386-1388.

5. Bensenor IM, Olmos RD, Lotufo PA. Hypothyroidism in the elderly: diagnosis and management. Clin Interv Aging. 2012;7:97-111.

6. Magri F, Muzzoni L, Cravello M, et al. Thyroid function in physiological aging and in centenarians: possible relationships with some nutritional markers. Metabolism. 2002;51(1):105-109.

7. Andersen-Ranberg K, Jeune B, Høier-Madsen M, Hegedüs L. Thyroid function, morphology and prevalence of thyroid disease in a populationbased study of Danish centenarians. J Am Geriatr Soc. 1999;47(10): $1238-1243$.

8. Mazzaccoli G, Pazienza V, Piepoli A, et al. Hypothalamus-hypophysisthyroid axis function in healthy aging. $J$ Biol Regul Homeost Agents. 2010;24(4):433-439.

9. Mariotti S, Franceschi C, Cossarizza A, Pinchera A. The aging thyroid Endocr Rev. 1995;16(6):686-715

10. Jolobe OMP. The upper limit of the normal range for TSH is higher with increasing age. Clin Interv Aging. 2012.
Clinical Interventions in Aging

\section{Publish your work in this journal}

Clinical Interventions in Aging is an international, peer-reviewed journal focusing on evidence-based reports on the value or lack thereof of treatments intended to prevent or delay the onset of maladaptive correlates of aging in human beings. This journal is indexed on PubMed Central, MedLine, the American Chemical Society's 'Chemical Abstracts Ser-

\section{Dovepress}

vice' (CAS), Scopus and the Elsevier Bibliographic databases. The manuscript management system is completely online and includes a very quick and fair peer-review system, which is all easy to use. Visit http://www.dovepress.com/testimonials.php to read real quotes from published authors. 